\title{
Chryseobacterium joostei sp. nov., isolated from the dairy environment
}

\author{
Celia J. Hugo, ${ }^{1}$ Paul Segers, ${ }^{2}$ Bart Hoste, ${ }^{3}$ Marc Vancanneyt ${ }^{3}$ and \\ Karel Kersters ${ }^{2}$ \\ ${ }^{1}$ Department of Microbial, Biochemical and Food Biotechnology, University of the Free State, \\ Bloemfontein 9300, South Africa \\ ${ }^{2,3}{ }^{2}$ aboratorium of Microbiology ${ }^{2}$ and BCCM/LMG Bacteria Collection ${ }^{3}$, University of Ghent, \\ K. L. Ledeganckstraat 35, Gent B-9000, Belgium
}

Correspondence

Celia J. Hugo

HugoCJ@sci.uovs.ac.za

\section{INTRODUCTION}

The taxonomy of the flavobacteria has changed drastically during the last 10 years, mainly as a result of rRNA similarity studies (Bernardet et al., 1996; Segers et al., 1993; Steyn et al., 1998; Takeuchi \& Yokota, 1992; Vancanneyt et al., 1996; Vandamme et al., 1994). The genus Flavobacterium was emended in 1996 (Bernardet et al., 1996) and several former Flavobacterium species, as well as novel species, were classified in the new genera Chryseobacterium, Empedobacter, Myroides, Sphingobacterium and Pedobacter (Bernardet et al., 1996; Steyn et al., 1998; Takeuchi \& Yokota, 1992; Vancanneyt et al., 1996; Vandamme et al., 1994; Yabuuchi et al., 1983; Yamaguchi \& Yokoe, 2000).

At the time of writing, the genus Chryseobacterium consists of six species, Chryseobacterium balustinum, Chryseobacterium gleum (type species), Chryseobacterium indologenes, Chryseobacterium indoltheticum, Chryseobacterium meningosepticum and Chryseobacterium scophthalmum, and the recently described protein-deaminating rice-field isolate 'Chryseobacterium proteolyticum' (Yamaguchi \& Yokoe, 2000). Except for C. meningosepticum, all these species belong to a multispecies taxonomic entity that also includes numerous unidentified clinical and environmental isolates that are often referred to as CDC group IIb (Holmes, 1992; Holmes et al., 1984a, b; Jooste et al., 1985, 1986a, b; King, 1959; Lijnen et al., 2000; Owen \& Snell, 1976; Ursing \& Bruun, 1991). These organisms can cause a variety of defects in dairy products, such as surface taint and apple odour in

The EMBL accession numbers for the $16 \mathrm{~S}$ rDNA sequences of C. joostei sp. nov. LMG $18212^{\top}$ and C. scophthalmum LMG $13028^{\top}$ are AJ271010 and AJ271009.

Full details of the antimicrobial sensitivity of strains of the novel species and reference strains are available as supplementary material in IJSEM Online. butter (Jooste, 1985; Jooste et al., 1986a). The heat-stable metalloproteases of these organisms may also cause problems in the dairy industry (Venter, 1997).

In previous studies (Hugo \& Jooste, 1997; Hugo et al., 1999), 103 South African dairy isolates and a large number of reference strains, all identified as, or related to, Chryseobacterium species or CDC group IIb, were studied using a polyphasic approach. Forty of the 103 strains studied could be identified as $C$. indologenes and one as C. gleum (Hugo et al., 1999). The other strains could not be classified in any of the existing species. Among these unidentified strains, two homogeneous taxa, one large and one small, were delineated. According to DNA-DNA hybridization values (Hugo et al., 1999) and the generally accepted standards for describing novel species (Vandamme et al., 1996; Wayne et al., 1987), only the large taxon (DNA group 3), containing 11 strains, was a candidate for a novel Chryseobacterium species. This taxon was studied extensively in the present work. On the basis of fatty acid methyl ester analysis, $16 \mathrm{~S}$ rDNA sequence analysis and phenotypic characterizations [biochemical tests, API ZYM (bioMérieux) profiles, antibiotic-susceptibility patterns and scanning and transmission electron microscopy], we propose the name Chryseobacterium joostei sp. nov. for this taxon.

\section{METHODS}

Bacterial strains. Strains used in this study are listed in Table 1. C. joostei strains were isolated from raw milk samples from various regions of South Africa (Jooste, 1985; Jooste et al., 1985, 1986a, b; Welthagen \& Jooste, 1992). The reference strains were received from culture collections or other research institutes (Mudarris et al., 1994; Ursing \& Bruun, 1991). A comparison with 'C. proteolyticum' was made using data from the literature (Yamaguchi \& Yokoe, 2000), as the proposed type strain was not available at the time of this study. Bergeyella zoohelcum and Empedobacter brevis were included for 
Table 1. Strains investigated and their sources of isolation

Abbreviations: ATCC, American Type Culture Collection, Manassas, VA, USA; CCUG, Culture Collection of the University of Göteborg, Sweden; GIFU, Department of Medical Microbiology, Gifu University School of Medicine, Japan; LMG, BCCM/LMG Bacteria Collection Laboratorium voor Microbiologie, Universiteit Gent, Belgium; NCTC, National Collection of Type Cultures, London, UK. Other strain designations were used by Jooste (1985), Welthagen \& Jooste (1992), Hugo \& Jooste (1997) and Hugo et al. (1999). RSA, Republic of South Africa.

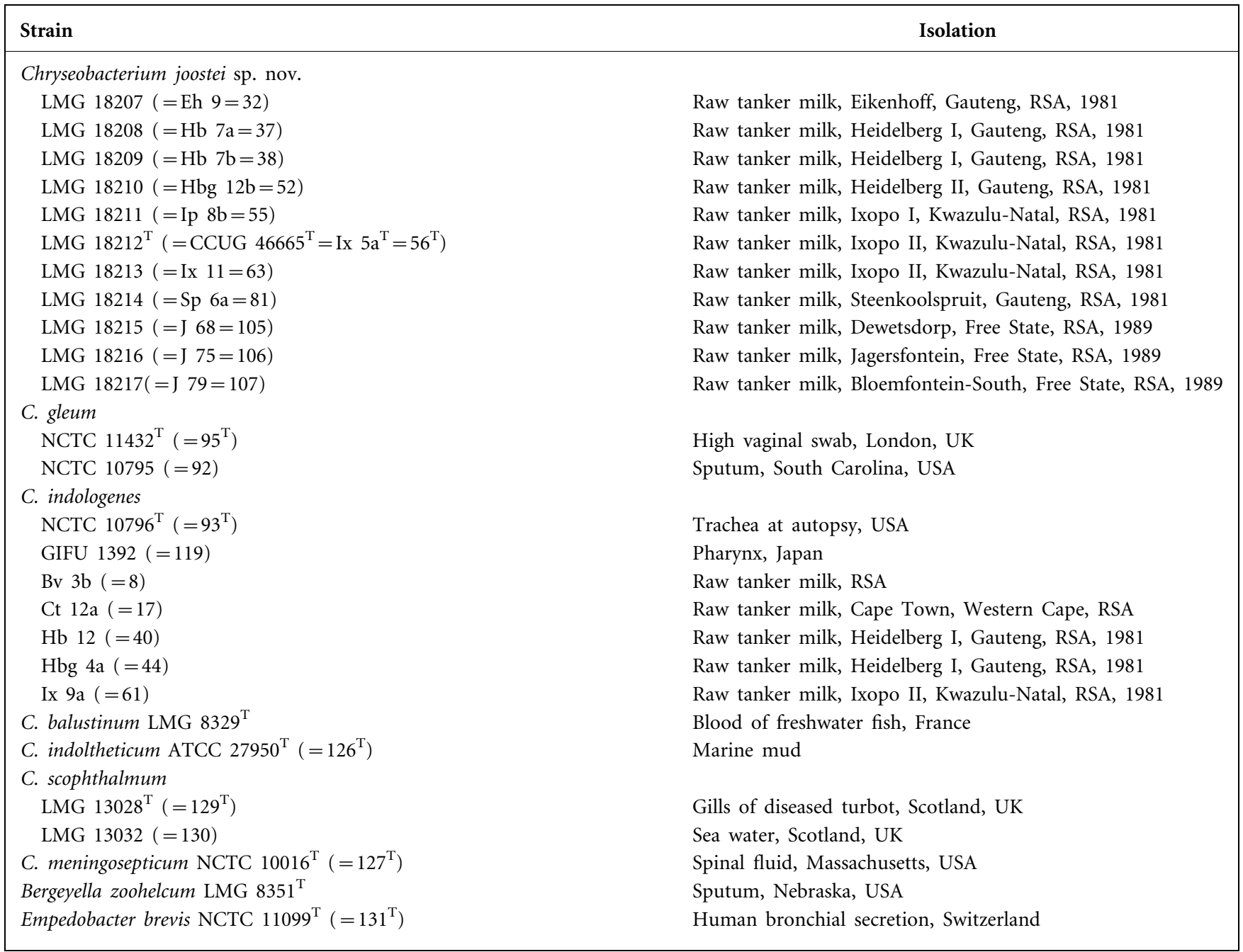

comparative purposes. All the isolates and reference strains were reactivated in nutrient broth (CM67; Oxoid) and checked for purity on nutrient agar $\left[1.5 \%(\mathrm{w} / \mathrm{v})\right.$ agar] at $25^{\circ} \mathrm{C}$ for $24-48 \mathrm{~h}$. The strains were maintained in a freeze-dried state on filter-paper discs and stored in screw-capped tubes at $-20^{\circ} \mathrm{C}$, and for longer times at $-80^{\circ} \mathrm{C}$ or by lyophilization.

16S rDNA sequencing. Two strains, C. joostei $\mathrm{LMG} 18212^{\mathrm{T}}$ and C. scophthalmum LMG $13028^{\mathrm{T}}$, were studied. High-molecular-mass DNA was prepared according to Vandamme et al. (1992). Part of the rDNA operon, comprising the nearly complete $16 \mathrm{~S}$ rDNA, was amplified using a PCR. The sequence of the forward primer was 5'-AGAGTTTGATCCTGGCTCAG-3' and that of the reverse primer was 5'-AAGGAGGTGATCCAGCCGCA-3' (respectively corresponding to positions 8-27 and 1541-1522 of the Escherichia coli $16 \mathrm{~S}$ rRNA numbering system). PCR-amplified $16 \mathrm{~S}$ rDNAs were purified using the QIAquick PCR purification kit (Qiagen). Sequence analysis was performed using an Applied Biosystems 377 DNA sequencer and the protocols of the manufacturer with the ABI PRISM BigDye
Terminator cycle sequencing ready reaction kit (with AmpliTaq DNA Polymerase, FS). The sequencing primers were those described by Coenye et al. (1999). Sequence assembly was performed by using the program AutoAssembler (Applied Biosystems) and phylogenetic analysis was performed by using the BIONUMERICS software (Applied Maths). The consensus sequence and sequences of strains belonging to the same phylogenetic group (retrieved from the EMBL database) were aligned and a phylogenetic tree was constructed on the basis of the neighbour-joining method.

Fatty acid methyl ester analysis. Reactivated cultures were streaked on trypticase soy agar [BBL; solidified with $1.5 \%(\mathrm{w} / \mathrm{v})$ Difco Bacto agar] and incubated at $28{ }^{\circ} \mathrm{C}$ for exactly $24 \mathrm{~h}$. From a loopful of harvested cells, fatty acid methyl esters were prepared, separated by GLC and identified by the Microbial Identification System software package (MIS version 3.9; Microbial ID), as described previously (Vandamme et al., 1992). Mean percentages and standard deviations were calculated for each taxon. 
Phenotypic characterization of the isolates. A battery of tests was selected to differentiate among Gram-negative, yellow-pigmented bacteria (Holmes et al., 1984a). Tests were performed at $25^{\circ} \mathrm{C}$ with different incubation times, according to Cowan (1974), MacFaddin (1980) or Gerhardt et al. (1981), unless indicated otherwise.

Colony morphology was observed on nutrient agar and the presence of flexirubin pigments was investigated by flooding the plates with $20 \%$ (w/v) potassium hydroxide (Fautz \& Reichenbach, 1980). Pigmentation was also examined on tyrosine agar and fluorescence was assessed using King's medium B (Gerhardt et al., 1981). Gram staining was done using the modified protocol of Lillie, as described by Cowan (1974). Motility was examined by phase-contrast microscopy from cells grown in nutrient broth at 22 and $37^{\circ} \mathrm{C}$. Gliding motility was determined on CY agar, as described by Jooste et al. (1985). Growth was investigated at different concentrations of sodium chloride $(0-5 \%, \mathrm{w} / \mathrm{v})$, at different temperatures $\left(5,22,37\right.$ and $\left.42^{\circ} \mathrm{C}\right)$ and on cetrimide agar (Brown \& Lowbury, 1965), $\beta$-hydroxybutyrate agar, MacConkey agar and Simmons' citrate agar. Haemolytic activity was determined using sheep-blood $(5 \%, \mathrm{v} / \mathrm{v})$ agar plates.

Additional biochemical tests were performed: oxidative or fermentative metabolism of glucose; oxidase, catalase, methyl red and VogesProskauer reactions; gluconate oxidation; reduction of selenite $(0 \cdot 4 \%, w / v)$, nitrate and nitrite (Cleve's acid was used instead of $\alpha$-naphthylamine); alkaline reaction on Christensen's citrate (Holmes et al., 1975); production of hydrogen sulphide (lead acetate paper and triple-sugar-iron methods), indole (Ehrlich's reagent and Kovács' indole reagent), 3-ketolactose; ammonia from arginine; activity of arginine dihydrolase, lysine decarboxylase, ornithine decarboxylase, phosphatase, DNase (Oxoid CM321; supplemented

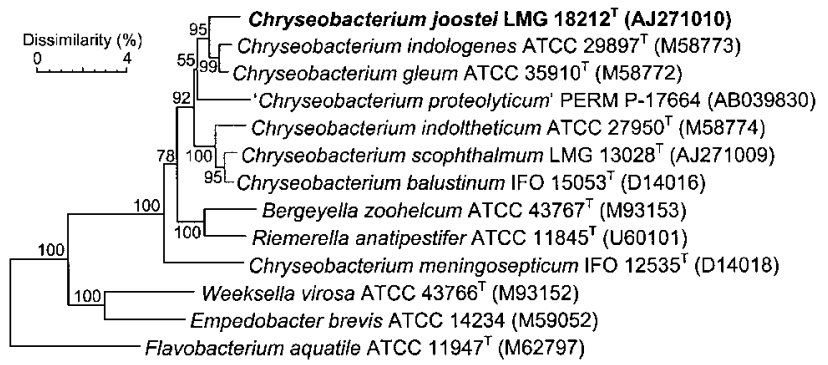

Fig. 1. Neighbour-joining tree of Chryseobacterium species and related taxa of the Flavobacteriaceae, showing the position of C. joostei sp. nov. LMG $18212^{\top}$. Accession numbers of $16 \mathrm{~S}$ rDNA sequences are indicated in parentheses. Bootstrap probability values are indicated at branch-points (100 trees resampled).

with $0 \cdot 01 \%$ toluidine blue), $\beta$-galactosidase (ONPG), lecithinase (opalescence on lecithovitellin agar), phenylalanine deaminase, urease on Christensen's urea agar; hydrolysis of aesculin, casein, gelatin (tube and plate method), starch, Tweens 20 and 80 and tyrosine; potassium cyanide tolerance; malonate utilization; and acid production from $10 \%(\mathrm{w} / \mathrm{v})$ glucose and lactose, from $1 \%(\mathrm{w} / \mathrm{v})$ adonitol, L-arabinose, cellobiose, dulcitol, ethanol, D-fructose, D-glucose, glycerol, inositol, lactose, maltose, D-mannitol, raffinose, rhamnose, sorbitol, sucrose, trehalose and D-xylose and from $0 \cdot 5 \%(\mathrm{w} / \mathrm{v})$ salicin.

Susceptibility to 26 antimicrobial agents was determined according to

Table 2. Long-chain fatty acid composition of Chryseobacterium species and related bacteria

Taxa are listed as: 1, C. joostei sp. nov. $(n=11) ; 2$, C. gleum $(n=5) ; 3$, C. indologenes $(n=45) ; 4$, C. balustinum $(n=1)$; 5 , C. indoltheticum $(n=1)$; 6, C. scophthalmum $(n=2) ; 7$, C. meningosepticum $(n=1) ; 8$, B. zoohelcum $(n=1)$; 9, Empedobacter brevis $(n=6)$. All strains identified as C. gleum, C. indologenes and Empedobacter brevis in an earlier study (Hugo et al., 1999) were included. Fatty acid percentages amounting to less than $1 \%$ of the total fatty acids in all strains were not included. Means $\pm \mathrm{SD}$ are given. tr, Trace (less than $1 \cdot 0 \%$ ); ND, not detected.

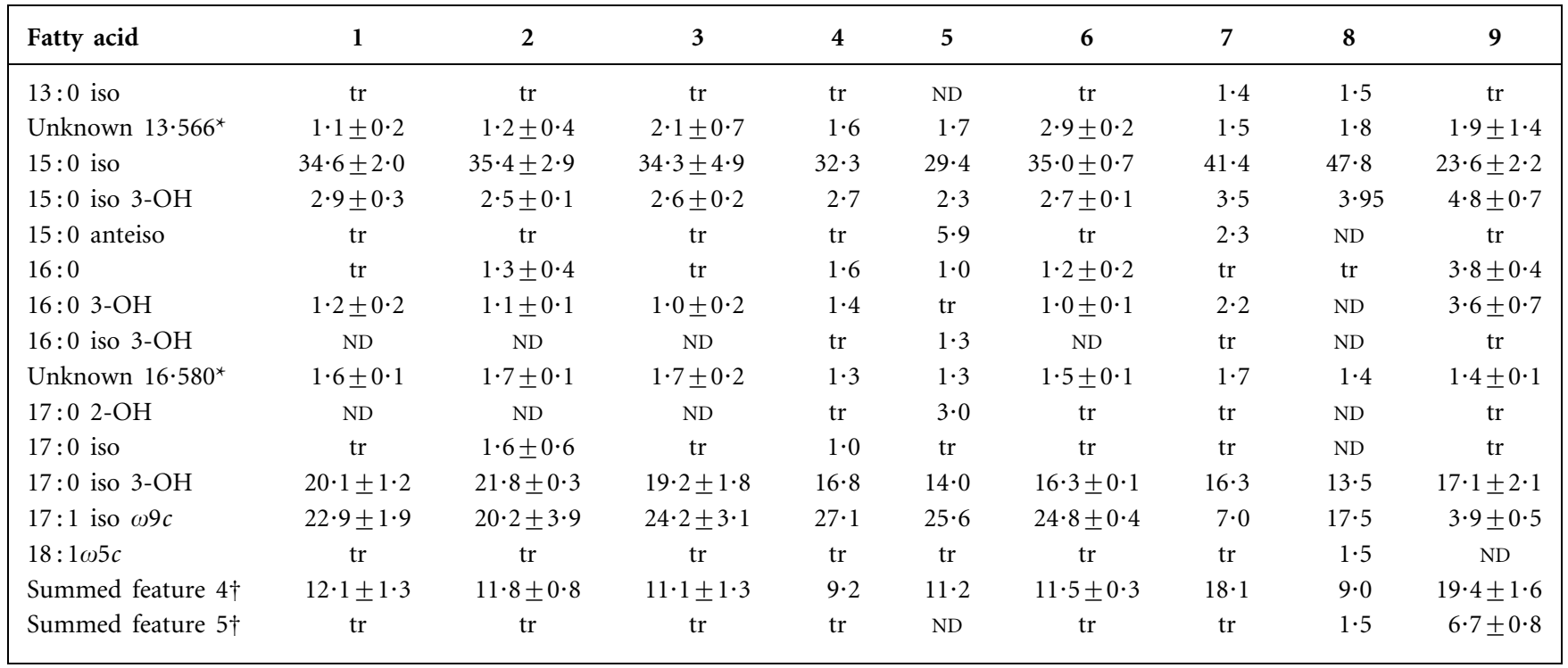

${ }^{\star}$ Unknown fatty acid; numbers indicate equivalent chain length.

$\dagger$ Fatty acids that could not be separated by GC using the Microbial Identification System (Microbial ID) software were considered summed features. Summed feature 4 contains $15: 0$ iso $2-\mathrm{OH}$ and/or $16: 1 \omega 7 c$ and/or $16: 1 \omega 7 t$. Summed feature 5 contains $17: 1$ iso I and/or $17: 1$ anteiso B. 
the standard methods of the NCCLS (1983). Strains were grown overnight on Mueller-Hinton agar (Oxoid) at $25^{\circ} \mathrm{C}$ and the diameters of inhibition zones were measured.

Hydrolysis of 19 substrates was investigated using the API ZYM system according to the recommendations of the manufacturer (bioMérieux). The intensity of the developed colour was measured on a scale from 0 to 5 and interpreted as being negative when values ranged between 0 and 1 and positive for values between 2 and 5 (Mudarris et al., 1994).

Electron microscopy. Dense suspensions of C. joostei LMG $18212^{\mathrm{T}}$ were cultivated in nutrient broth at $25^{\circ} \mathrm{C}$ for $72 \mathrm{~h}$. Cell preparation was done according to Spurr (1969) and Reynolds (1963). For transmission electron microscopy, a Philips CEM 300 electron microscope was used; a JEOL 6400 WINSEM electron microscope was used for scanning electron microscopy.

\section{RESULTS AND DISCUSSION}

\section{Phylogenetic allocation and strain characterization}

16S rDNA sequence analysis and subsequent construction of a neighbour-joining tree (Fig. 1) confirmed that C. joostei LMG $18212^{\mathrm{T}}$ and C. scophthalmum LMG $13028^{\mathrm{T}}$, a species for which no sequence was previously available, are authentic members of the genus (Mudarris et al., 1994). Respective sequence similarities of $97 \cdot 7$ and $97 \cdot 6 \%$ between C. joostei LMG $18212^{\mathrm{T}}$ and the type strains of C. gleum and C. indologenes did not exclude a possible relationship at the species level with one of these taxa (Vandamme et al., 1996). Similarities in the range $95 \cdot 8-87 \cdot 3 \%$ between C. joostei

Table 3. Differential phenotypic characteristics of Chryseobacterium species and related bacteria

Species are listed as: $1, C$. joostei sp. nov. $(n=11) ; 2$, C. gleum $(n=2) ; 3$, C. indologenes $(n=7) ; 4$, C. balustinum $(n=1) ; 5$, C. indoltheticum $(n=1) ; 6$, C. scophthalmum $(n=2) ; 7$, C. meningosepticum $(n=1) ; 8$, B. zoohelcum $(n=1) ; 9$, Empedobacter brevis $(n=1)$; 10 , 'C. proteolyticum' ( $n=2$; data from Yamaguchi \& Yokoe, 2000). +, Positive; -, negative; V, variable; D, delayed; NA, not available; W, weakly positive.

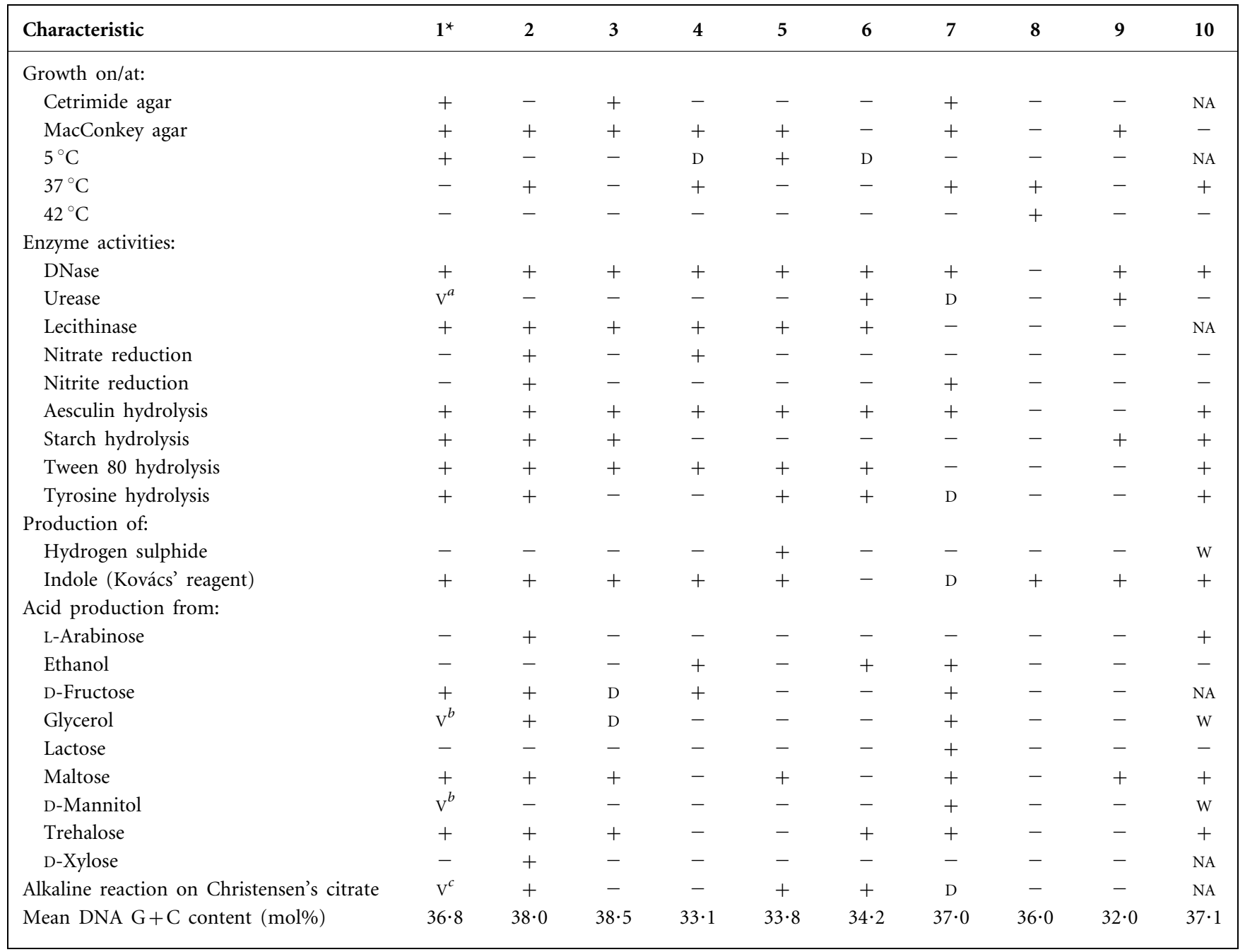

${ }^{*}$ Variable reactions are scored as: $a$, positive for LMG $18212^{\mathrm{T}}$ and 18213 ; $b$, positive for LMG $18207-18211,18212^{\mathrm{T}}, 18213,18214$ and 18217 ; c, positive for LMG 18208-18211, 18212 ${ }^{\mathrm{T}}, 18215$ and 18216. 
LMG $18212^{\mathrm{T}}$ and reference strains of C. balustinum, C. indoltheticum, C. meningosepticum, 'C. proteolyticum', C. scophthalmum, Riemerella anatipestifer, B. zoohelcum, Empedobacter brevis and Weeksella virosa were below the level indicating relatedness at the species level (Stackebrandt \& Goebel, 1994).

The mean long-chain fatty acid contents of all C. joostei strains and related taxa (except 'C. proteolyticum') are presented in Table 2. Fatty acid methyl ester analysis revealed minor differences between $C$. joostei and its nearest phylogenetic neighbours C. gleum, C. indologenes, C. indoltheticum, C. balustinum and C. scophthalmum. Dominant fatty acids for all strains investigated (mean levels above $5 \%$ ) were $15: 0$ iso, $17: 0$ iso $3-\mathrm{OH}, 17: 1$ iso $\omega 9 c$ and summed feature 4 (15:0 iso $2-\mathrm{OH}$ and/or $16: 1 \omega 7 c$ and/or $16: 1 \omega 7 t$, Table 2 ). This fatty acid composition is characteristic of all of the above-mentioned taxa, including CDC group IIb strains (Hugo et al., 1999). Significant differences were observed between the latter organisms and C. meningosepticum, B. zoohelcum and Empedobacter brevis (Table 2).

\section{Evidence for the proposal of a novel species}

DNA-DNA hybridizations between C. joostei (DNA group 3; Hugo et al., 1999) and the two species that showed significant $16 \mathrm{~S}$ rDNA similarity for possible relatedness at the species level, C. gleum and C. indologenes, showed low DNA binding values (19-23\%; Hugo et al., 1999). A separate position for the $C$. joostei strains with respect to the other Chryseobacterium species was also shown previously by SDS-PAGE of whole-cell proteins (SDS-PAGE group 5; Hugo et al., 1999).

In view of the separate position determined genomically and chemotaxonomically, an extensive comparative phenotypic study was performed. Results from this polyphasic approach confirm that $C$. joostei constitutes a novel species of the genus Chryseobacterium (Mudarris et al., 1994; Vandamme et al., 1994). Phenotypic features that distinguish the novel species from its nearest neighbours are summarized in Table 3.

\section{Description of Chryseobacterium joostei sp. nov.}

Chryseobacterium joostei (joos'te.i. N.L. gen. n. joostei of Jooste, in honour of P. J. Jooste, who isolated the first strains of this species from South African raw milk).

Cells are Gram-negative, non-spore-forming rods, approximately $1 \cdot 0 \times 0.5 \mu \mathrm{m}$ with parallel sides and rounded ends (Fig. 2). The cell wall is approximately $50 \mathrm{~nm}$ thick (Fig. 2). Cells do not show gliding motility on CY agar and are nonmotile after incubation in nutrient broth at 22 and $37^{\circ} \mathrm{C}$ (phase-contrast microscopy). Growth is aerobic. Colonies on nutrient agar are smooth, shiny, circular with entire edges and butyrous in consistency, becoming mucoid after incubation for 5 days. A bright-yellow pigment (flexirubin)

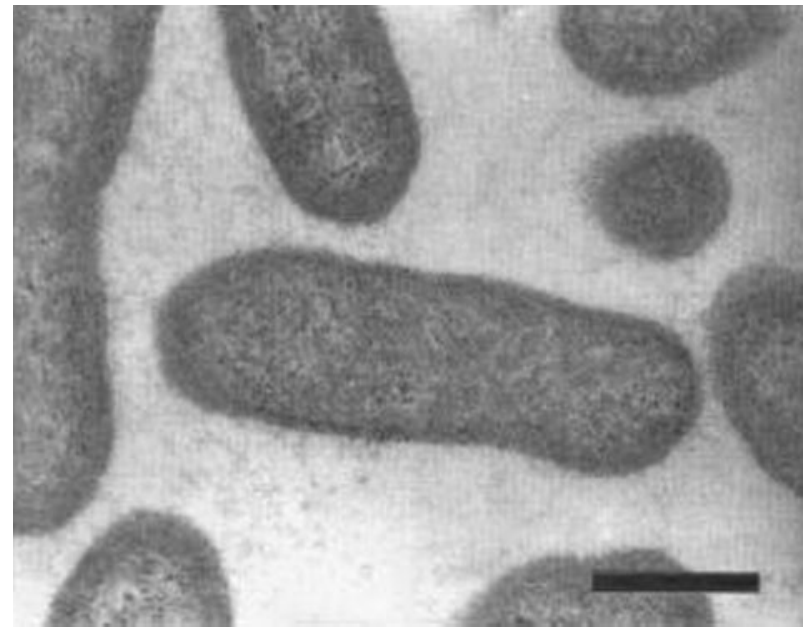

Fig. 2. Transmission electron micrograph of a cross-section of cells of C. joostei sp. nov. LMG $18212^{\top}$. Bar, $500 \mathrm{~nm}$.

is produced on nutrient agar: it is non-diffusible, nonfluorescent and turns reddish brown upon the addition of $20 \% \mathrm{KOH}$. A water-soluble, non-diffusible brown pigment is produced on tyrosine agar. Strains grow at $5{ }^{\circ} \mathrm{C}$ and room temperature, but not at 37 or $42^{\circ} \mathrm{C}$. Growth is observed on cetrimide agar, MacConkey agar and $\beta$-hydroxybutyrate (without the production of $\beta$-hydroxybutyrate inclusion granules), but not on Simmons' citrate agar. All strains show catalase, oxidase, phosphatase, DNase and lecithinase (opalescence on lecithovitellin agar) activity, but not arginine, lysine or ornithine decarboxylase or phenylalanine deaminase activity; there is no gluconate oxidation. They produce indole when Kovács' reagent is used, but not when Ehrlich's reagent is used. Hydrogen sulphide and 3-ketolactose are not produced. Capable of hydrolysing aesculin, casein, gelatin, starch, Tweens 20 and 80 and tyrosine. Negative for the methyl red and Voges-Proskauer tests, does not tolerate $\mathrm{KCN}(0 \cdot 0075 \%)$, does not utilize malonate and cannot reduce nitrate, nitrite or $0.4 \%$ selenite. Acid is produced from $1 \%(\mathrm{w} / \mathrm{v})$ D-fructose, D-glucose (not $10 \%, \mathrm{w} / \mathrm{v}$ ), maltose and trehalose, but not from L-arabinose, cellobiose, dulcitol, ethanol, inositol, lactose, raffinose, rhamnose, salicin, sorbitol, sucrose or D-xylose. Results from API ZYM tests are given in Table 4. Susceptible to the following antimicrobial agents: chloramphenicol $(50 \mu \mathrm{g})$, nalidixic acid $(30 \mu \mathrm{g})$, novobiocin $(5 \mu \mathrm{g})$ and sulphamethoxazole $(25 \mu \mathrm{g})$. Variable results for ampicillin $(25 \mu \mathrm{g})$, carbenicillin $(100 \mu \mathrm{g})$, cephaloridine $(30 \mu \mathrm{g})$ and clindamycin $(2 \mu \mathrm{g})$; full details are available as supplementary material in IJSEM Online. The cellular longchain fatty acids characterizing the species are 15:0 iso, $15: 0$ iso $3-\mathrm{OH}, 16: 03-\mathrm{OH}, 17: 0$ iso $3-\mathrm{OH}, 17: 1$ iso $\omega 9 c$, summed feature 4 ( $15: 0$ iso $2-\mathrm{OH}$ and/or $16: 1 \omega 7 c$ and/or $16: 1 \omega 7 t)$ and two unidentified fatty acids with equivalent chain lengths of 13.566 and $16 \cdot 580$ (Table 2). The G+C content of the DNA is about $36-37 \mathrm{~mol} \%(36 \cdot 7 \mathrm{~mol} \%$ for the type strain). 
Table 4. API ZYM profiles of Chryseobacterium species and related bacteria

Species are listed as: 1, C. joostei sp. nov.; 2, C. gleum; 3, C. indologenes; 4, C. balustinum; 5, C. indoltheticum; 6, C. scophthalmum; 7, C. meningosepticum; 8, B. zoohelcum; 9, Empedobacter brevis. Only type strains of each species were included. All the organisms gave positive reactions for 2-naphthyl phosphate, 2-naphthyl caprylate, L-leucyl 2-naphthylamide, L-valyl 2-naphthylamide, 2-naphthyl phosphate and naphthol-AS-BI phosphate and gave negative reactions for 2-naphthyl myristate, 2-naphthyl $\beta$-Dgalactopyranoside, naphthol-AS-BI $\beta$-D-glucuronide and 6-Br-2-naphthyl $\alpha$-D-mannopyranoside. API ZYM scores were interpreted as described in Methods.

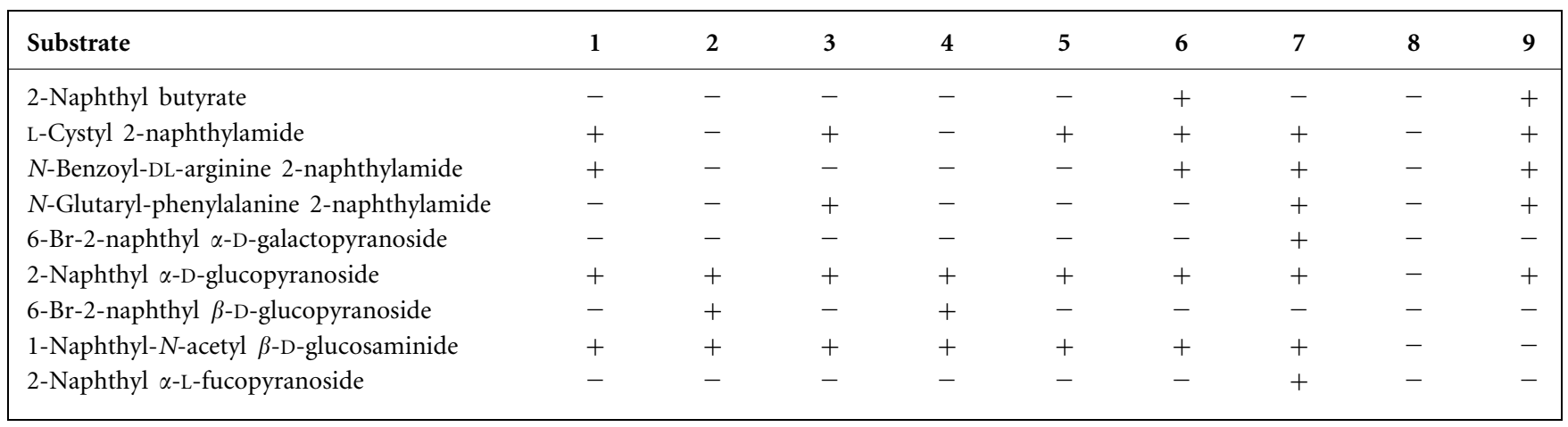

The type strain is LMG $18212^{\mathrm{T}}\left(=\mathrm{Ix} 5 \mathrm{a}^{\mathrm{T}}=\operatorname{CCUG} 46665^{\mathrm{T}}\right)$, which was isolated in 1981 from raw milk in the Ixopo district of Kwazulu-Natal in South Africa. All C. joostei strains reported in this study were isolated from raw milk samples taken from different farms and from tankers arriving at dairy factories across South Africa.

\section{ACKNOWLEDGEMENTS}

C. J. H. is grateful to the Central Research Fund of the University of the Free State for the financial means to perform this study and to the Electron Microscope Unit of the University of the Free State (Dr P. van Wyk) for the scanning and transmission electron microscopy.

\section{REFERENCES}

Bernardet, J.-F., Segers, P., Vancanneyt, M., Berthe, F., Kersters, K. \& Vandamme, P. (1996). Cutting a Gordian knot: emended classification and description of the genus Flavobacterium, emended description of the family Flavobacteriaceae, and proposal of Flavobacterium hydatis nom. nov. (basonym, Cytophaga aquatilis Strohl and Tait 1978). Int J Syst Bacteriol 46, 128-148.

Brown, V. I. \& Lowbury, E. J. L. (1965). Use of an improved cetrimide agar medium and other culture methods for Pseudomonas aeruginosa. J Clin Pathol 18, 752-756.

Coenye, T., Falsen, E., Vancanneyt, M., Hoste, B., Govan, J. R. W., Kersters, K. \& Vandamme, P. (1999). Classification of Alcaligenes faecalis-like isolates from the environment and human clinical samples as Ralstonia gilardii sp. nov. Int J Syst Bacteriol 49, 405-413.

Cowan, S. T. (1974). Cowan and Steel's Manual for the Identification of Medical Bacteria, 2nd edn. Cambridge: Cambridge University Press.

Fautz, E. \& Reichenbach, H. (1980). A simple test for flexirubin-type pigments. FEMS Microbiol Lett 8, 87-91.

Gerhardt, P., Murray, R. G. E., Costilow, R. N., Nester, E. W., Wood, W. A., Krieg, N. R. \& Phillips, G. B. (1981). Manual of Methods for General Bacteriology. Washington, DC: American Society for Microbiology.
Holmes, B. (1992). The genera Flavobacterium, Sphingobacterium, and Weeksella. In The Prokaryotes, 2nd edn, vol. 4, pp. 3620-3630. Edited by A. Balows, H. G. Trüper, M. Dworkin, W. Harder \& K.-H. Schleifer. Berlin: Springer.

Holmes, B., Lapage, S. P. \& Malnick, H. (1975). Strains of Pseudomonas putrefaciens from clinical material. J Clin Pathol 28, 149-155.

Holmes, B., Owen, R. J. \& McMeekin, T. A. (1984a). Genus Flavobacterium Harrison, Breed, Hammer and Huntoon 1923, 97 ${ }^{\mathrm{AL}}$. In Bergey's Manual of Systematic Bacteriology, vol. 1, pp. 353-361. Edited by N. R. Krieg \& J. G. Holt. Baltimore: Williams \& Wilkins.

Holmes, B., Owen, R. J., Steigerwalt, A. G. \& Brenner, D. J. (1984b). Flavobacterium gleum, a new species found in human clinical specimens. Int J Syst Bacteriol 34, 21-25.

Hugo, C. J. \& Jooste, P. J. (1997). Preliminary differentiation of food strains of Chryseobacterium and Empedobacter using multilocus enzyme electrophoresis. Food Microbiol 14, 133-142.

Hugo, C. J., Jooste, P. J., Segers, P., Vancanneyt, M. \& Kersters, K. (1999). A polyphasic taxonomic study of Chryseobacterium strains isolated from dairy sources. Syst Appl Microbiol 22, 586-595.

Jooste, P. J. (1985). The taxonomy and significance of FlavobacteriumCytophaga strains from dairy sources. $\mathrm{PhD}$ thesis, University of the Orange Free State, South Africa.

Jooste, P. J., Britz, T. J. \& de Haast, J. (1985). A numerical taxonomic study of Flavobacterium-Cytophaga strains from dairy sources. J Appl Bacteriol 59, 311-323.

Jooste, P. J., Britz, T. J. \& Lategan, P. M. (1986a). The prevalence and significance of Flavobacterium strains in commercial salted butter. Milchwissenschaft 41, 69-73.

Jooste, P. J., Britz, T. J. \& Lategan, P. M. (1986b). Screening for the presence of Flavobacterium strains in dairy sources. S Afr J Dairy Sci 18, 45-50.

King, E. O. (1959). Studies on a group of previously unclassified bacteria associated with meningitis in infants. Am J Clin Pathol 31, 241-247.

Lijnen, H. R., Van Hoef, B., Ugwu, F., Collen, D. \& Roelants, I. (2000). Specific proteolysis of human plasminogen by a $24 \mathrm{kDa}$ endopeptidase from a novel Chryseobacterium sp. Biochemistry 39, 479-488. 
MacFaddin, J. F. (1980). Biochemical Tests for Identification of Medical Bacteria, 2nd edn. Baltimore: Williams \& Wilkins.

Mudarris, M., Austin, B., Segers, P., Vancanneyt, M., Hoste, B. \& Bernardet, J.F.(1994). Flavobacterium scophthalmum sp. nov., a pathogen of turbot (Scophthalmus maximus L.). Int J Syst Bacteriol 44, 447-453.

NCCLS (1983). Performance standards for antimicrobial disk susceptibility tests. Tentative standard, vol. 3, no. 14. Villanove, PA: National Committee for Clinical Laboratory Standards.

Owen, R. J. \& Snell, J. J. S. (1976). Deoxyribonucleic acid reassociation in the classification of flavobacteria. J Gen Microbiol 93, 89-102.

Reynolds, E. S. (1963). The use of lead citrate at high $\mathrm{pH}$ as an electron-opaque stain in electron microscopy. J Cell Biol 17, 208-221.

Segers, P., Mannheim, W., Vancanneyt, M., de Brandt, K., Hinz, K.-H., Kersters, K. \& Vandamme, P. (1993). Riemerella anatipestifer gen. nov., comb. nov., the causative agent of septicemia anserum exsudativa, and its phylogenetic affiliation within the FlavobacteriumCytophaga rRNA homology group. Int J Syst Bacteriol 43, 768-776.

Spurr, A. R. (1969). A low-viscosity epoxy resin embedding medium for electron microscopy. J Ultrastruct Res 26, 31-43.

Stackebrandt, E. \& Goebel, B. M. (1994). Taxonomic note: a place for DNA-DNA reassociation and $16 \mathrm{~S}$ rRNA sequence analysis in the present species identification in bacteriology. Int J Syst Bacteriol 44, 846-849.

Steyn, P. L., Segers, P., Vancanneyt, M., Sandra, P., Kersters, K. \& Joubert, J. J. (1998). Classification of heparinolytic bacteria into a new genus, Pedobacter, comprising four species: Pedobacter heparinus comb. nov., Pedobacter piscium comb. nov., Pedobacter africanus sp. nov. and Pedobacter saltans sp. nov. Proposal of the family Sphingobacteriaceae fam. nov. Int J Syst Bacteriol 48, 165-177.

Takeuchi, M. \& Yokota, A. (1992). Proposals of Sphingobacterium faecium sp. nov., Sphingobacterium piscium sp. nov., Sphingobacterium heparinum comb. nov., Sphingobacterium thalpophilum comb. nov., and two genospecies of the genus Sphingobacterium, and synonymy of Flavobacterium yabuuchiae and Sphingobacterium spiritivorum. J Gen Appl Microbiol 38, 465-482.

Ursing, J. \& Bruun, B. (1991). Genotypic heterogeneity of Flavobacterium group IIb and Flavobacterium breve demonstrated by DNA-DNA hybridization. APMIS 99, 780-786.
Vancanneyt, M., Segers, P., Torck, U., Hoste, B., Bernardet, J.-F., Vandamme, P. \& Kersters, K. (1996). Reclassification of Flavobacterium odoratum (Stutzer 1929) strains to a new genus, Myroides, as Myroides odoratus comb. nov. and Myroides odoratimimus sp. nov. Int J Syst Bacteriol 46, 926-932.

Vandamme, P., Vancanneyt, M., Pot, B. \& 10 other authors (1992). Polyphasic taxonomic study of the emended genus Arcobacter with Arcobacter butzleri comb. nov. and Arcobacter skirrowii sp. nov., an aerotolerant bacterium isolated from veterinary specimens. Int J Syst Bacteriol 42, 344-356.

Vandamme, P., Bernardet, J.-F., Segers, P., Kersters, K. \& Holmes, B. (1994). New perspectives in the classification of the flavobacteria: description of Chryseobacterium gen. nov., Bergeyella gen. nov., and Empedobacter nom. rev. Int J Syst Bacteriol 44, 827-831.

Vandamme, P., Pot, B., Gillis, M., De Vos, P., Kersters, K. \& Swings, J. (1996). Polyphasic taxonomy, a consensus approach to bacterial systematics. Microbiol Rev 60, 407-438.

Venter, H. (1997). Purification and characterisation of a heat stable metalloprotease from a Chryseobacterium of dairy origin. MSc thesis, University of the Orange Free State, South Africa.

Wayne, L. G., Brenner, D. J., Colwell, R. R. \& 9 other authors (1987). International Committee on Systematic Bacteriology. Report of the ad hoc committee on reconciliation of approaches to bacterial systematics. Int J Syst Bacteriol 37, 463-464.

Welthagen, J. J. \& Jooste, P. J. (1992). Isolasie en karakterisering van gepigmenteerde psigrotrofe bakterieë uit verkoelde roumelk. $S$ Afr J Dairy Sci 24, 47-52 (in Afrikaans).

Yabuuchi, E., Kaneko, T., Yano, I., Moss, C. W. \& Miyoshi, N. (1983). Sphingobacterium gen. nov., Sphingobacterium spiritivorum comb. nov., Sphingobacterium multivorum comb. nov., Sphingobacterium mizutae sp. nov., and Flavobacterium indologenes sp. nov.: glucosenonfermenting gram-negative rods in CDC groups IIK-2 and IIb. Int J Syst Bacteriol 33, 580-598.

Yamaguchi, S. \& Yokoe, M. (2000). A novel protein-deamidating enzyme from Chryseobacterium proteolyticum sp. nov., a newly isolated bacterium from soil. Appl Environ Microbiol 66, 3337-3343. 